\title{
Achieving Business Excellence Prize: The Case Of Trimo Trebnje d.d.
}

Metka Tekavcic, (E-mail: metka.tekavcic@ef.uni-lj.si), University of Ljubljana, Slovenia Darja Peljhan, (E-mail: darja.peljhan@ef.uni.lj.si), University of Ljubljana, Slovenia

\begin{abstract}
The late 1980s and early 1990s saw a global realization of the strategic importance of quality, and many countries established programmes to recognize quality and excellence. Companies pursuing an excellence strategy soon recognized that the award frameworks offered more than just a vehicle for recognition. The frameworks were seen to be best-practice models for implementing excellence strategies, performing self-assessments, benchmarking and, ultimately, delivering improved performance. The purpose of this paper is twofold. First, we present the business excellence from the European Foundation for Quality Management (EFQM) Excellence model point of view. Second, we describe how employee results, customer results, and favourable society results are achieved through leadership driving policy and strategy, people, partnerships and resources, and processes, which ultimately lead to excellence in key performance results in a manufacturing company that won the 2002 Slovene National Quality Award based on the EFQM Excellence model.
\end{abstract}

\section{Introduction}

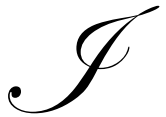

$\mathrm{n}$ the last two decades, companies have experienced a period of great change in their markets and operations. International competition has meant that many organizations have faced an increasingly turbulent and hostile environment. Customers have become more demanding, competition has become more intense and sophisticated, and the pace of technological change has quickened. As a result, many organizations have adopted a range of improvement approaches in response to these circumstances. We have seen the growing adoption of quality management standards such as ISO 9000, the emergence of total quality management (TQM), business process re-engineering (BPR), business excellence, performance thinking, Six Sigma etc. (Porter, Tanner, 2004, page 3).

Business excellence, like quality, has to be managed - it will not just happen. Clearly it must involve everyone in the process and be applied throughout the organization (Oakland et al., 2002, page 1126). The involvement of people in the continuous improvement and transformation of business processes is a fundamental theme that runs through all of quality improvement, process improvement and excellence approaches. Essentially, the core themes of excellence are the following (Porter, Tanner, 2004, page 6):

- Leadership: The specific leadership behaviours of setting a clear direction and values for the organization, creating customer focus, and empowering the organization and its people in the pursuit of excellence are key to all excellence approaches.

- $\quad$ Customer focus: The customer is the final judge of product quality and service delivery. Customer loyalty and retention are best achieved by understanding the current and future needs of current and prospective customers.

- $\quad$ Strategic alignment: All the excellence models stress the importance of strategic development, alignment and planning.

- Organizational learning, innovation and improvement: Stimulating individual and organizational learning, innovation and improvement through the effective sharing of knowledge and information is a critical element in an excellence approach. 
- $\quad$ People focus: A company's success is highly dependent upon the knowledge, skills, creativity and motivation of its people. This 'people potential' is best harnessed through shared values supported by a culture of trust and empowerment.

- $\quad$ Partnership development: Companies need to develop longer-term strategic mutually beneficial partnerships with a range of external partners, including customers, suppliers and education organizations. Successful longer-term partnerships focus on delivering sustained value for the partners.

- $\quad$ Processes management: The focus of all excellence approaches is on designing processes to meet customer requirements, systematically managing processes on the basis of facts and improving processes on the basis of customer feedback from the process itself. Process capability is based on the ability of the company's processes to meet customer requirements.

- $\quad$ Result focus: Excellence is concerned with creating value for all the key stakeholders, including customers, employees, suppliers and partners, the public and the community at large. Balancing the needs of all these key stakeholders is a critical part of developing successful strategies.

- $\quad$ Social responsibility: Responsibility to the public, ethical behaviour and good citizenship are important in an excellence approach, and are critical for the long-term interest of the company.

The late 1980s and early 1990s saw a global realization of the strategic importance of quality, and many countries established programmes to recognize quality and excellence. These initiatives followed the earlier example of Japan, which started to recognize quality practices with the launch of the Deming Prize in 1951. Companies pursuing an excellence strategy soon recognized that the award frameworks offered more than just a vehicle for recognition. The frameworks were seen to be best-practice models for implementing excellence strategies, performing self-assessments, benchmarking and, ultimately, delivering improved performance.

As such, quality award criteria such as the Japanese Deming Prize, the American Malcolm Baldridge National Quality Award (MBNQA), and the European Foundation for Quality Management's (EFQM) Excellence Award are continuously being used by organizations in both the private and public sectors to carry out selfassessments to measure their improvement progress and potential. Each of the award criteria provides a framework of standardized items against which a company can measure its performance. This standardization allows comparisons to be made and best-in-class performance identified. Winning one of these annual awards is a prestigious event, but applicants frequently cite the most beneficial aspect to be the assessment process itself (Porter, Tanner, 2004, pages 65-66).

Over the last ten years the award frameworks and award processes across the world have continued to improve as the latest ideas on quality and excellence have been incorporated. In this process there has been increasing convergence of all the excellence models and, whilst we are still some way from a 'Unified Global Model', most of the models have a high degree of commonality.

The purpose of this paper is twofold. First, we present the business excellence from the European Foundation for Quality Management (EFQM) Excellence model point of view. Second, we describe how employee results, customer results, and favourable society results are achieved through leadership driving policy and strategy, people, partnerships and resources, and processes, which ultimately lead to excellence in key performance results in a manufacturing company that won the 2002 Slovene National Quality Award based on the EFQM Excellence model. It is not our purpose to discuss total quality management in detail. Readers who want to upgrade their knowledge in this area can consult, for example, Fink, 2000; Khan, 2000; Rampersad, 2001; Russell and Taylor, 1998; Stamatis, 1997.

The rest of the paper is organized as follows. First, we briefly introduce the EFQM Excellence Model. Then we discuss quality in Slovenia, with special emphasis on the Slovene national quality award for business excellence. Finally, we present the case of Slovene company which won the 2002 Slovene National Quality Award. 


\section{The EFQM Excellence Model}

In September 1988, the presidents of fourteen leading West European companies signed a letter of intent to establish the European Foundation for Quality Management (EFQM). The foundation was officially established in October 1989 with the goal of promoting business excellence and TQM in Europe and assisting its members in their TQM efforts. In October 1991 the EFQM, with the support of the European Union and the European Organization for Quality (EOQ), launched the European Quality Award (EQA), based on the framework of the EFQM's European Model for Total Quality Management. The EQA Model was first TQ-based self-assessment framework to place an emphasis on business results. Over the last decade the model has seen ongoing development, with a shift in emphasis from a TQM model to an excellence model (see Figure 1), although many of the TQ core values have been retained or enhanced.

Figure 1: The EFQM Excellence Model

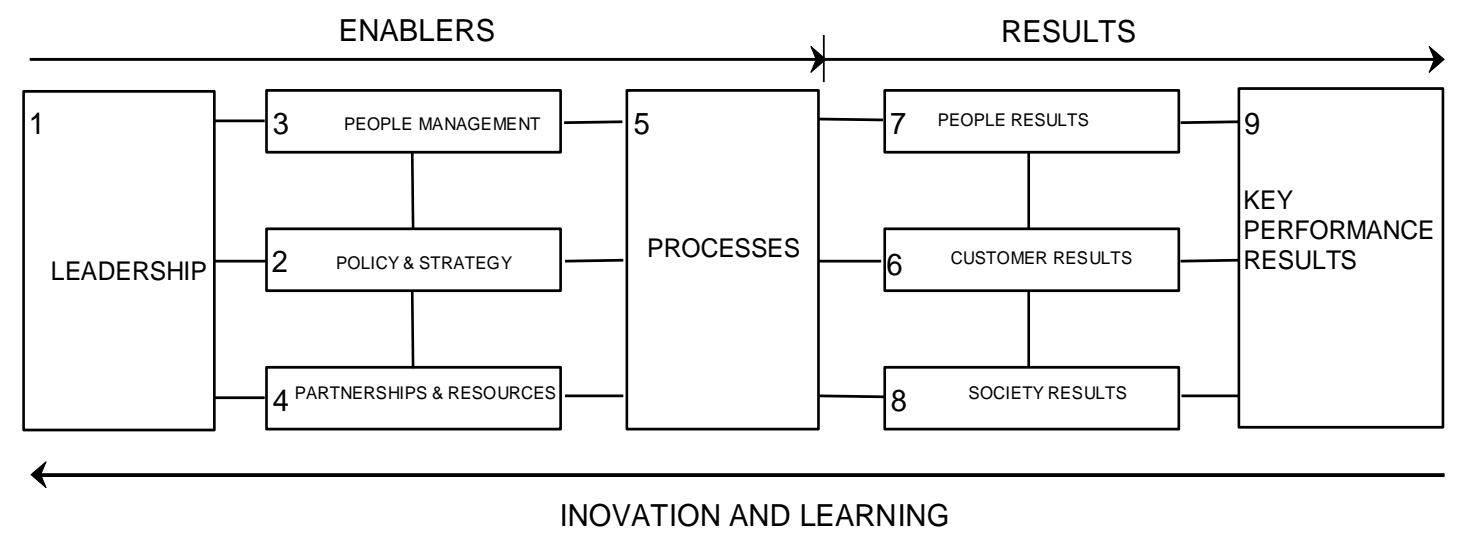

Source: Porter and Taner, 2004, page 69.

Figure 1 displays graphically the principle of the full Excellence Model. Essentially, people (employee) results, customer results, and favourable society results are achieved through leadership driving people, policy and strategy, partnerships and resources, and processes, which lead ultimately to excellence in key performance results. Hence, the enablers deliver the results that, in turn, drive innovation and learning. The EFQM has provided a weighting for each criteria that may be used in scoring self-assessments and making awards. The EFQM has thus built a model of criteria and a review framework against which a company may face and measure itself, to examine any 'gaps'. Such a process is known as self-assessment (Oakland et al., 2002, page 1127). Used as intended, the EFQM Excellence Model provides an ideal framework for managing and continuous improvement in an organization (Sandbrook, 2001, page 84).

The launch of the award has generated a considerable interest in self-assessment in Europe. Many national awards (such as the Slovene National Quality Award) have subsequently been launched, and these have accelerated the use of self-assessment. In particular, the EFQM Excellence Model, with its strong performance emphasis, has made a significant contribution to integrating excellence approaches and TQM into the mainstream business activities of many companies. ${ }^{1}$

\section{Quality in Slovenia}

Slovenia is a small economy with a population of about 2 million. It was founded in June 1991. It is a small country with a land area of 20,296 square km, neighboring Italy in the West, Austria in the North, Hungary in the East and Croatia in the South. It has been a constitutional part of former socialist republic Yugoslavia in the period 
1945-1991. The business environment in Slovenia has changed radically in the last 13 years. Slovenia has been faced with the triple transition process: the transition to an independent state, the reorientation from the former Yugoslav to the Western market, and the transition to the market economy.

When Slovenia became an independent state in 1991, it lost a rather large Yugoslav market. Companies' markets began to change dramatically. Slovenian industry has succeeded in finding substitute markets. National economy had some advantages due to the positive legacy of its Yugoslav past that gave Slovenian companies a sizeable head start over the rest of the Central and East European (CEE) region when it came to transition. Slovenian companies had been exposed to the market economy for decades and had had traditional trade links with Western European companies. Slovenia has remained one of the most successful economies in Central and East Europe. This fact is reflected in the high GDP per capita at around $€ 10,500$ which exceeds $70 \%$ of the EU average. In the beginning of the transition period, state-owned (i.e. socially-owned) companies encountered an entirely different business environment. Companies were facing privatization and changes in top management, companies' strategic and tactical planning, operations, etc.

Slovenia is not the only CEE country facing transition period difficulties. Apart from Yugoslavia, some other countries also split up (Czechoslovakia, the Soviet Union). Firms in these countries lost a significant part of their domestic markets while their traditional export markets also disappeared. Companies in transitional economies were entering an open competitive environment. They had to face the deregulated and liberalized business environment. The problem was that many of CEE companies were neither flexible nor customer oriented. This is the reason why they had to rethink and / or change basic management tools they were using in order to survive in turbulent business environment. Moreover, some companies began to use these tools for the first time. Due to its successful transition process, Slovenia may be considered as a 'benchmark' for the majority of transitional economies in the region. From May 1, 2004, Slovenia has been a full member of the European Union. Companies are therefore faced with intensive processes of deregulation and liberalization of the foreign trade regime. They are facing increasing foreign competition. Major changes in the business environment strongly influenced the introduction of TQM in proactive and outward oriented companies. Practically all CEE countries were in some sort of transition period during the last decade. Despite many remaining imperfections, these countries now have functioning market economies. This is the reason why our findings and main conclusions regarding the case of a successful Slovenian manufacturing company can be applied to all companies facing transition period difficulties and operating in turbulent environments that want to achieve business excellence.

There are over 130,000 companies in Slovenia, the majority (98\%) being small businesses with up to 50 employees. The narrower public sector comprises of some 3,000 institutions. In the past ten years, we have seen a boost of quality management systems in Slovenia with the award of 1,200 ISO 9000 and 180 ISO 14000 certificates. There has been a strong interest in introducing the European Excellence Model through participations in the programme of the Slovene National Quality Award. The key driving force of these processes has been the transition to the EU markets and the markets of other developed countries during the period since Slovenia became independent.

At the beginning, the introduction of quality standards in Slovenia was more intense in the private sector. Now, it is becoming more and more evident that a good public sector performance is equally important for the successful development of a country, especially as regards the quality of life of the population in general. Since 1991, the main organizer of the national technical quality infrastructure has been Metrology Institute of the Republic of Slovenia (MIRS). Among other assignments, MIRS coordinates of the National Quality Award. It is an initiator and promoter of the introduction of up-to-date quality management systems. MIRS has established close partnerships with about 100 experts in the field of National Quality Award to build up a system of assessors and jurors. As regards National Quality Award, MIRS has been, since the very beginning in 1995, an initiator, organizer and financer of the activities for establishing the system of the "Business Excellence Prize of the Republic of Slovenia", which is known in Slovenia by the PRSPO abbreviation (Skubic et al., 2004, str. 1-2). 


\section{The Slovene National Quality Award}

In the years 1993-1994, the National Quality Programme activities started, and that marked the beginning of Slovene National Quality Award (Slovene abbreviation is PRSPO and is used in the paper). It is based on the Republic of Slovenia Business Excellence Prize Act, which was adopted in 1998. PRSPO is fully funded from the State budget and managed by a Board appointed by the Slovenian Government. MIRS builds up, maintains and coordinates the system and performs the necessary systematic, technical and administrative tasks for the needs of PRSPO. Since 1995, MIRS has been an active member of EFQM, and since 2002, a National Partner Organization.

Following two successful pilot projects, the first regular application and assessment process for the Slovenian companies was launched in 1998. Firstly, they encourage companies which have already been certified against ISO 9000 standard to join the programme. The Slovene Business Excellence Prize is the highest recognition given by the Republic of Slovenia within the national quality programme for the achievements in the field of quality of products and services as well as business quality. The award is based on the nine criteria of the EFQM Model, and the award process is very similar to the EFQM award process. It is conferred on by the Slovene Prime Minister during the Award Ceremony. The Prize may be applied for by the Slovenian business enterprises, institutions and other legal entities, as well as the state authorities wishing to introduce systems for attaining advanced business processes, thus ensuring competitive advantage to their products and services.

\section{Introducing the case company: Trimo Trebnje d.d. ${ }^{2}$}

Trimo operates in the business of engineering and production of pre-fabricated buildings. The company was established in 1961 and achieved the major turnover in 1992 with new top management. Trimo is internationally oriented as $67 \%$ of its sales come from abroad. Their main products include prefabricated steel buildings, steel structures, façades, roofs, containers, and sound-isolating systems. Their key financial data and number of employees are presented in Table 1.

Table 1: Trimo's key financial data and number of employees

\begin{tabular}{|l|c|c|}
\hline Element & Value & Index 2002/2001 \\
\hline Total revenues (2002) & $€ 66.4 \mathrm{~m}$ & 106 \\
\hline Net profit (2002) & $€ 2.1 \mathrm{~m}$ & 102 \\
\hline Equity (31 December 2002) & $€ 23.3 \mathrm{~m}$ & 108 \\
\hline Number of employees (31 December 2002) & 444 & 104 \\
\hline
\end{tabular}

Source: Trimo's Annual Report 2002.

Trimo is oriented towards business excellence in all areas of their business. They implemented many management tools to help them achieve this goal:

- $\quad$ In 1993 they implemented ISO 9001.

- In 1995 they introduced continuous improvement in the form of 'Process of continuous improvement' programme (Trimo's abbreviation for it is PKI).

- In 1996 'Total Property Care' programme was introduced. 'Total property care' programme facilitates involvement of all employees in implementing changes, improving efficiency, reducing bottlenecks and costs, improving quality, safety and company's image.

- In 1997 Trimo entered the self-assessment process according to standards of the 'Republic of Slovenia Award for Business Excellence' (this was the pilot project of business excellence). It was granted an award. Also the ISO 9001 system was improved (first introduced in 1993).

- $\quad$ In 1998 they participated in the Slovene project of business excellence.

- In 1999 Trimo was chosen as one of the three best mid-sized Slovene companies and therefore received the award of the Republic Slovenia for Business Excellence. 
- In 2000 they implemented Customer Relationship Management (CRM) ${ }^{3}$ and obtained ISO 14001. Trimo was one of the founding members of the Learning Organization Institute. They organized the first Environmental Day. Managing Director (CEO) received an award by the Slovenian Chamber of Commerce for outstanding achievements in business and economy for the year 2000.

- In 2001 they further upgraded their Total Quality Management (TQM) programme, which has been the important part of strategic directions of the company from 1992 on.

- $\quad$ In 2002 they started to implement Balanced Scorecard (BSC) ${ }^{4}$ and were awarded the Republic of Slovenia Award for Business Excellence in the category of companies with more than 250 employees.

Trimo's vision is to become the leading European company offering complete solutions in the area of steel buildings. Their mission is to ensure original and complete solutions in the area of steel buildings. Special emphasis is placed on the accomplishment of solutions which help their customers achieve success. Since they think in a holistic manner, they develop the potential of each individual in the company, enable them to gain new knowledge and offer favourable conditions for personal development and creativity. They have built a financially sound company that assures ample return on equity (in $2002 \mathrm{ROE}$ was $9.7 \%$ ). They also foster the long-term development of a company that all Trimo shareholders can be proud of. Trimo is a company organized according to modern principles. It is a highly technologically capable joint-stock company that has operated in the international market for many years.

Trimo's goal is to become the first choice for all buyers of pre-fabricated steel facilities. They control the technologies of the future and produce top quality building materials. In the construction process they are committed to participating in all phases, from the draft concept to the complete facility. Complete solutions are their answer to any project. They strive to implement the boldest architectural ideas. Trimo has its own development, design, assembly and service departments as well as its own production line. Any buyer can therefore obtain an efficient and complete quotation for pre-fabricated facilities: from draft concept to completed facility. With their business partners they strive to create long-term relationships in order to build successful partnerships. They emphasize the individuality of each of their customers in order to offer ever more. They provide special and comprehensive solutions tailored to individual customer's needs since they wish to become and intend to remain the first choice of every customer. They organize annual meetings with their business partners which open enormous possibilities for socializing and creating even closer and more genuine relationships. Trimo wishes to be recognized for offering excellent quality products together with a complete service that can be adapted to each individual customer's needs.

The model of Business Excellence has been used in the process of self-evaluation since 1997 and the company has participated in the process of Business Excellence of the Republic of Slovenia since 1998. Trimo was rewarded the Republic of Slovenia Award for Business Excellence in 2002 in the category of legal entities with over 250 employees in the area of products. The reward was conferred by the Government of the Republic of Slovenia, Board for business excellence awards of the Republic of Slovenia. Although the economic environment was extremely unfavourable for the sale of investment goods, especially in the building sector in Slovenia and EU countries (which represent the most important Trimo's markets) in 2002, Trimo succeeded to achieve the following business performance results (Trimo's Annual Report 2002):

- Total revenues were $€ 66.4 \mathrm{~m}$ which represents a $6 \%$ increase compared to 2001 .

- $\quad$ Net profit amounted to $€ 2.1 \mathrm{~m}$ and represents a $2 \%$ increase compared to 2001.

- $\quad$ Value added per employee was $€ 29,500$.

- $\quad$ Export revenues were generated in over 40 countries world-wide.

\section{The enabler criteria in Trimo}

The enabler criteria are concerned with the company's approach to running its business. They represent the 'how's' rather than the 'what's' (Porter, Tanner, 2004, page 163). In the following sections we discuss five enabler criteria in Trimo: leadership, people management, policy and strategy, partnerships and resources, and processes. 


\section{Leadership}

Trimo's management facilitates the achievement of the company's mission and vision. They develop organizational values and systems required for sustainable success and implement these via their actions and behaviours. They inspire other employees to follow continuous improvement.

Total quality has been a very important part of an organizational culture and strategic directions of the company from 1992 on, when they established strategic programme of total quality which has been constantly upgraded year by year. In the last decade, total quality management is the philosophy of employees' activities in all levels of organization. They strive to continually improve their processes, products, services, and employees and other stakeholders relationships. From 1995 they do this systematically within the on-going programme 'Process of Continuous Improvements'. This is their way to improve their annual performance, while searching for more rational solutions of doing business. They encourage changes. For example, from the leadership perspective, they upgraded their vision in 2001 to include implementation of complete solutions for their customers.

In 2002 they began to develop the philosophy 'Trimo: facilitator of talents'. Leadership of the company estimates that the best talents with the best ideas are the key element for the future long-term sustainable growth of the company. Top management and other employees are continually educated and trained in the area of total quality. Top management benchmarks their improvements with competition. Top management transfer their knowledge to all levels of organization as they organize educational seminars and workshops throughout the company. Each year top management organizes special seminars for the groups of 50 to 100 employees, in which they present company position in the market, changes in the environment and inside the company, especially in the areas that affect the future activities of employees. In 2002, they focused on the new knowledge and skills acquisition, so that employees would be able to create new, different products, services, processes, increasing value added etc. as they are customer-focused company. In that way all employees receive equal information as regards the company standards, organizational culture, vision, mission, strategic goals, and the necessary activities to achieve them. Trimo's experience shows that anticipated and timely information and education facilitates the changes in operations activities. By the end of top management's presentations, participants fill in the questionnaire, which checks up their knowledge, and the satisfaction with and effectiveness of leadership approaches.

Top management is accessible to every employee. They constantly communicate with working teams and every employee can contribute to possible improvements by giving suggestions in writing or orally to their team leader or directly to the top management. Members of a working team actively cooperate by giving suggestions for improvements. The suggestion that receives the majority support is defined as a project, with a project manager, members of the project team (members can be cross-functional depending on the nature of the project), objectives, and deadlines. The essential contribution to the continuous improvements are projects within the PKI initiative. The number of suggestions per employee within the PKI represents one of the criteria for promotion.

Managers control key performance indicators once a week. Reports are prepared by middle managers and are then communicated to top management. Middle managers prepare actions for improving minor deviations, while major deviations are considered by the top management that weekly adopts necessary corrective measures to achieve short- and long-term goals.

Top management uses special questionnaires to check understanding of the mission, vision, values and whole organizational culture among employees. The results for 2002 show that $98 \%$ of employees know essential company values. Understanding of the above mentioned characteristics is well demonstrated in daily employees' activities, inside and outside the company. Leaders are actively included in the process of continuous improvement that is facilitated by flat organizational structure and team working with the common goal of continuous improvement for customers, employees, shareholders and other stakeholders. In 2001 they started to implement the process organization, which will sustain their customer focus. However, their major challenge in this area is IT and IS modernization. 
Top management works intensively with the most important customers who are often the source of new ideas for the improvement of Trimo's performance. They work closely with top suppliers to improve the quality of materials. Further, they regularly meet with architects and engineers to inform them about the latest product innovations and technological opportunities. They enhance the system of total quality with the help of experienced consulting firm from Germany. In the implementation of BSC they cooperate with the Slovene consulting firm.

\section{Policy and strategy}

Trimo implements its mission and vision by developing a stakeholder-focused ${ }^{5}$ strategy that takes into account the market and sector in which it operates. Policies, plans, objectives, and processes are developed and deployed to deliver the strategy. The main strategic objective is to achieve a sustainable growth of the company.

Due to quick changes in its environment, Trimo is forced to abandon some of its practices, products, technologies, processes, customers, suppliers, markets, etc. in order to develop new strategies or change existing strategies in time to ensure long-term sustainable growth of the company. They measure strategic goals according to the value they are adding. In the development of their strategies they use the following tools: SWOT analysis, Balanced Scorecard, Customer Relationship Management, value chain, and other tools. The key factor in achieving the company's goals is its employees.

They monitor the achievement of strategic goals every six months, while the implementation of annual plans is controlled weekly. Corrective measures are taken as soon as negative deviations are reported. Employees are informed about the company's results. The shareholders are notified about the major results five times a year. Company also issues the newspaper 'Shareholders' news once a year. Trimo changes its strategy according to the changes in its business environment. They have very good experience with flexible actions as they face continually reaching or even exceeding of short- and long-term goals in the last decade. They remain focused on their customers' needs.

Total quality demands a systematic approach. The performance according to the certificate ISO 9001 (acquired in 1993) and 14001 (acquired in 2000) has been constantly upgraded by numerous projects rationalizing operations and improving quality of products and services. The most important projects have been the following: programme of Total Quality Management (TQM), Customer Relationship Management (CRM), Process of Continuous Improvements (PKI), Total property care (CSI) and a learning organization.

\section{People management}

Trimo manages, develops and releases the full potential of its people at an individual, team-based and organizational level. The company promotes fairness and equality and involves and empowers its people. Management cares for, communicates and recognizes employees' achievements, in a way that motivates people and builds commitment to using their skills and knowledge for the benefit of the company.

In the year 2002 Trimo decided to transform itself from production type of the company to the highly technological and engineering company. Therefore, the share of low-educated employees is falling, while the share of the highly educated people is rising. In the period 1997-2002 the share of highly educated people rose from $20 \%$ to $30 \%$. In the year 2002 it reached $35 \%$.

In the area of employee development their strategically most important area is education of all employees as this represents the major source of intellectual capital enhancement and the opportunity to manage changes rapidly. The average in 2002 was 50 hours of education and training per employee. Top management has at least 150 hours of education and training per year, while middle managers have at least 100 hours of education and training per year. In Trimo, they educate their business partners (engineers, suppliers, cooperators) as well. This type of education is intended to promote new technological achievements and quality standards. The goal of the company is to become a learning organization that enables long-term company development. Trimo is one of the founders of Learning Organization Institute in Slovenia which was established to promote the exchange of information and 
knowledge among the most successful Slovenian companies as well as to facilitate benchmarking in different areas of their operations.

Trimo's production workers are qualified to perform work in at least two areas in production of one or more production lines. Trimo's philosophy is the following: Each employee is responsible for their personal and professional development. The role of the company is to facilitate this development. Employees perform changes and improvements in the 'Process of continuous improvement' and in the 'Total property care' programme as well as in the form of formal and informal working teams.

PKI -'Process of Continuous Improvement' was introduced in 1995. Its goal is to stimulate creativity of all employees and to involve them in the process of improvements. Employees give suggestions for improvements in their working area. The instigator of the improvement is always involved in the implementation of the suggested idea. The formal methodology for the process was elaborated in 1997. Each suggestion comprises of clearly stated objectives, activites, deadlines, costs and team members. Each implementation project is performed by the team of 4 to 8 members who come from functional areas which would be affected by the proposed change. In 1996 they have established a special commission that evaluates each project and rewards the best projects according to special criteria. Each employee has the so called 'Trimo appraisal interview' with his superior once a year. The purpose of 'Trimo dialogue' is to evaluate employee's progress during the year and to set his or her main targets to be achieved the next year. Employees are encouraged to give suggestions regarding their work improvements.

\section{Partnerships and resources}

Trimo plans and manages external partnerships, suppliers and internal resources in order to support policy and strategy and the effective operation of process. During planning and whilst managing partnerships and resources they balance the current and future needs of the organization, the community and the environment.

As regards financial resources, they control their use monthly. As Trimo is capital intensive company, they have developed special process of evaluating investments. Trimo has achieved the best ratings in financial institutions and it received non-refundable sources for undertaking R\&D and ecological projects. They will strive to further reduce the risks on the side of accounts receivable, extend the payment days to suppliers and to achieve discounts on early payments to suppliers.

They have partnership relations with their key suppliers who are actively involved in the R\&D processes of new products and in improvement processes of current products. Suppliers take a part of the risk associated with these endeavours, they commit themselves to following quick changes in the field of implementing new technologies, developing new products and environmental friendly materials. Suppliers are updating their processes to satisfy Trimo's high quality standards. With this process they drastically reduced the number of complaints about materials, in some cases even to 0\%. From 1993 they organize annual meetings with their key suppliers, where they present them Trimo's vision, corporate strategy and procurement strategy and goals. Suppliers are also invited to attend the annual meeting organized for all Trimo's business partners. With regular suppliers they meet at least every quarter of the year, with some even on a weekly basis. Suppliers are also involved in the PKI programme as they can give suggestions for performance improvements in a specially designed questionnaire. Trimo monitors the level of materials inventories weekly. Their goal is to achieve monthly inventories turnover, but sometimes this doesn't seem feasible as they are also striving to satisfy the customer needs very quickly and buy and have in stock some materials to avoid possible bottlenecks.

As regards the technology, Trimo uses highly developed and environmental friendly technologies that result in achieving repeatedly top-level quality of their products and in increasing of value added per employee. Their goal is to develop at least three new products per year. In corporate strategy they defined that the main source of sustainable long-term growth is their own R\&D. They organized R\&D center, which cooperates with renowned experts from Slovenia and abroad. Their priority is the development of new products and new technologies with high value added per employee. They invest $4 \%$ of their sales to R\&D activities which is comparable with or better than their competition. In the period 1999-2002 more than $20 \%$ of their sales came from new or improved products. 


\section{Processes}

Trimo designs, manages and improves processes in order to fully satisfy, and generate increasing value for customers and other stakeholders. Since 1992, they have written in their strategy that satisfied customers bring the highest profit. Their long-term goal is to operate according to high ethical standards and that their customers will get at least what they expect to get. Such decisions make Trimo to anticipate and be ahead of customers needs. Since 1999 they have used the methodology of systematic permanent strategic customers monitoring and new strategic customers acquisition. In 2002 they launched Customer Relationship Management programme. Trimo was granted the ISO 9001 certificate among the first companies in Slovenia in 1993. In 2000 it was awarded also ISO 14000.

Trimo's key processes are the following:

- $\quad$ Marketing and market research;

- $\quad$ Education and training of employees and business partners;

- $\quad$ R\&D of new products and technologies;

- $\quad$ Production processes and assembling;

- $\quad$ Process of continuous improvement;

- $\quad$ After-sale services.

Key performance indicators of these processes are systematically controlled and presented to the top management once a week. According to their trends, top management decides to take corrective measures if necessary and then regularly control the effectiveness of these actions. Key processes are defined with a corporate strategy, which is updated annually on the Strategic business conference at which key factors are defined as follows: customer satisfaction, employee satisfaction, good business results, and positive attitude towards the environment. Trimo believes that they can achieve business excellence only if everyone in their value chain is excellent.

\section{The results criteria}

The results criteria are concerned with what the company has achieved and is achieving. They comprise customer results, people results, society results, and key performance results.

\section{Customer results}

In 2002 Trimo generated $67 \%$ of total sales in foreign markets, especially due to the expanded network of Trimo's companies, representative offices and agents. The most important markets were Slovenia, Austria, Croatia, Germany, Russia, and Serbia and Montenegro. Trimo products were displayed in 15 fairs all over Europe. Trimo assures complete solutions in the area of steel prefabricated buildings: from an idea and draft to the finished building. Such system offers a wide range of buildings: industrial, commercial, shopping, business, sports, cultural as well as buildings of prestigious importance. Steel prefabricated buildings are made of steel structures, roofs and facades. Roofs and facades are made of the Trimoterm fireproof panels or the Trimoval profiled metal sheet. While $66 \%$ of the total sales of steel constructions and $83 \%$ of the sales of the Trimoval steel metal sheet were accomplished in the domestic market, the share of the Trimoterm fireproof panels sales in foreign markets amounted to $77 \%$. The sales in foreign markets represent $95 \%$ of the total container sales. Trimo's major container customers are from Austria, Denmark, and Germany.

Trimo doesn't provide only building constructions for its customers. It provides complete solutions and value for them. Customers are in the focus of all Trimo's activities. Their goal is to find a suitable and reliable solution adjusted to customer individual needs. Often, these solutions are found in co-operation with customers. They continuously improve their products and introduce many innovative solutions to satisfy their customers. In 2000 they began to systematically employ 'Customer Relationship Management' programme which enables them to ensure appropriate and reliable solutions that are customer tailored. They build long-term relationships with their customers. They systematically monitor employee satisfaction from 1990. They have developed unified questionnaire for investors, construction companies, and licence partners. The share of satisfied customer increases 
every year. In 2003 all customers believed that Trimo was their desired long-term partner, while this share was around 94-96\% in the period 2001-2002 (Customer Satisfaction Report 2003). In 1999, 97\% of Trimo customers would recommend Trimo's products to others, while in 2000 and $200198 \%$ of Trimo customers would recommend Trimo's products to others. Trimo do not apply mass marketing, they communicate with an individual customer.

Other tools in monitoring customer satisfaction include complaints analysis, professional fair information analysis and analysis of information from sales people who contact customers directly. Trimo perceives a customer complaint as the opportunity to improve. Their goal is to retrieve the complaint in 48 hours in the case of an urgent matter. In other cases they react in three days at most. In the area of steel constructions they practically have no complaints at all ( $1 \%$ of the whole complaints).

Trimo would like to become and remain the first choice for their customers as regards providing them with complete solutions. That is why they build and sustain long-term partner relationships with their customers. Many Slovene and foreign multi-national companies believe in Trimo. They are well aware that penetration in new markets is easier in co-operation with reliable partners.

People results

Trimo's employees are aware of the personal responsibility for the success of the company. They take initiatives for their professional and personal growth as well as for the development of the department where they work and the whole company. Over 33\% of all employees have at least University degree or diploma (see Figure2). Trimo's commitment to top results motivates and stimulates every individual to constant improvements. Employees have acquired new skills and knowledge in various areas of the entrepreneurial management, foreign languages, computer training, quality and professional training. In 2002 each employee attended training or courses of 48 hours on average (see Figure 3).

Figure 2

Share of employees with at least University degree or diploma

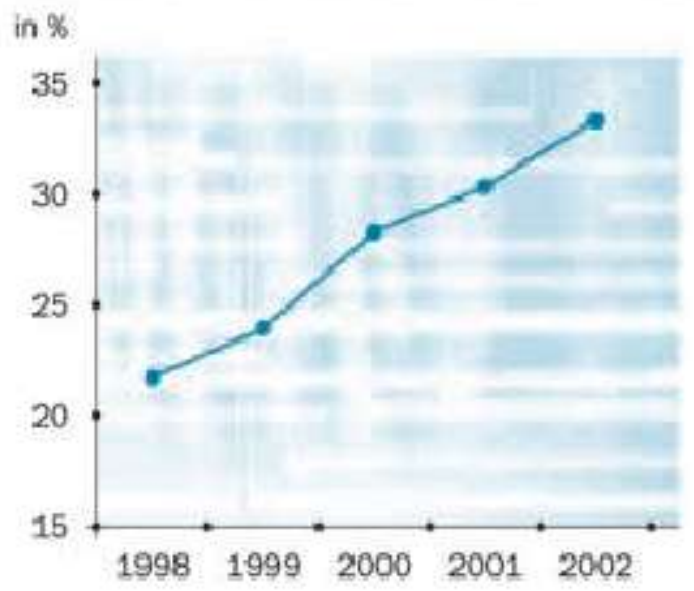

Source: Annual Report 2002, Trimo. 


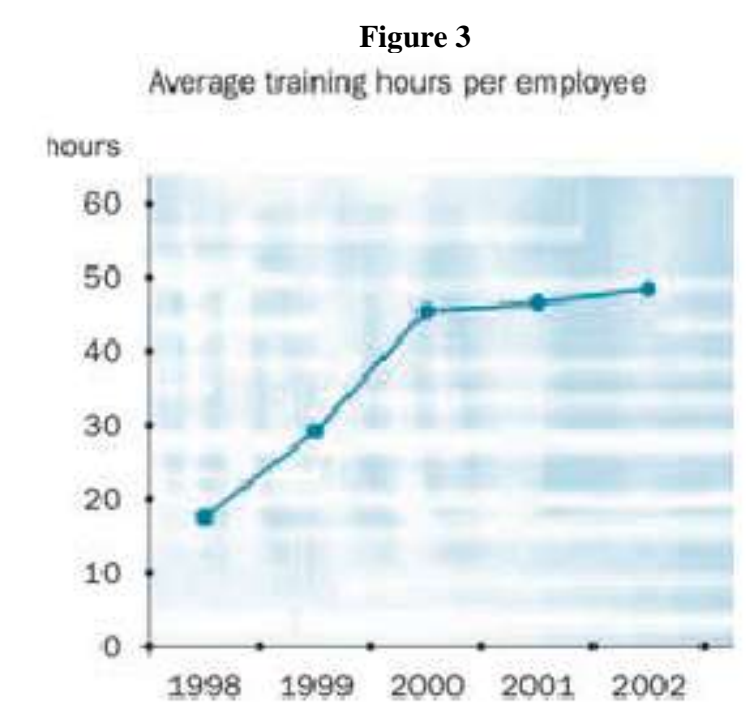

Source: Annual Report 2002, Trimo.

The success of the company is attained through the efforts of ambitious people who are qualified and willing to constantly upgrade their knowledge and share it with their colleagues at work, people who are innovative and effect changes. Training and professional and personal growth are made possible for individuals in an international business environment. Promotion is in accordance with results. They work in teams and project groups and are classified as a learning organization. They trust and help each other. They are glad if an individual achieves success. They act according to high ethical and professional standards. Honesty is the highest ranked value. Initially, each individual is responsible for their professional and personal development and the company helps in the realisation of educational and other objectives. Company's experts co-operate with world-famous institutions and participate in international conferences. Employee satisfaction is systematically monitored from 2001. They found out that employees identify themselves with the organizational culture and values.

\section{Society results}

Trimo is responsible to the community where it operates. They are actively involved in the life of the local environment. In 2002 they organized the third Environmental Day, on which employees, their families and inhabitants of the local community were invited to attend. For years Trimo has supported sportsmen and sports events, artists and performers, and charity events. They also help various associations, societies, clubs, schools and kindergartens. Trimo is the sponsor of the Handball Club Trimo Trebnje, Skiing Club Trimo Trebnje, and the Indoor Football Club Trimo Trebnje.

Trimo offers training and employment possibilities to young people. They were granted an 'Employment award' for their contribution to the improvement of the employment possibilities in the region where they operate (that is Dolenjska). Their scholarships were mostly received by students of mechanical and civil engineering. By conferring research awards in 2001 for young researchers, Trimo invited them for the first time to submit their research work and contest for Trimo Research Awards for the best University, Masters' and Doctoral Thesis, aiming to improve the co-operation with the Slovene universities and research institutes. Due to the favourable response, the invitation was renewed in 2002 and Trimo conferred 12 University thesis awards, 7 Masters' thesis awards and 1 Doctoral Thesis award.

Environmental awareness is a fundamental element of their business strategy. They invest in the development of environmentally friendly products and technologies. Together with suppliers and other business partners they have developed closed life cycles of products where secondary raw materials are returned to the 
production process. The use of quality materials enables the development and production of safe and healthy products. Each year, during special education days, employees receive strategic training in the field of safety and health at work. They continuously invest in knowledge and technology enabling the implementation of their health, quality and environmental policy. They give their ongoing support to sports, cultural and humanitarian activities. Trimo would like to be recognized and famous for its positive attitude toward the protection of the environment and people's health. Their products and technologies are environmentally friendly. They have introduced the system of environmental management according to ISO 14001 in 1999 and upgraded it in 2002 with the elements of managing safety and health at work according to OHSAS 18001. Therefore, they joined the activities of the risk control in natural environment and those risks appearing in the working environment.

\section{Key performance results}

Trimo measures its performance with respect to the key elements of their policy and strategy. A special attention has always been paid to the long-term growth and development of the company. The financially strong company brings satisfaction and pride to the owners. Trimo belongs to the companies with the best credit status. The largest credit status company in the world, Dun \& Bradstreet, awarded Trimo the credit rating of A1. So far, Trimo meets high expectations of the owners who believe in Trimo and support decisions of the management as regards new investments, development of new products and technologies as well as penetration in the new markets. Trimo's financial results in 2002 were the following: total revenues were $€ 66.4 \mathrm{~m}$ which represents a $6 \%$ increase compared to 2001; net profit amounted to $€ 2.1 \mathrm{~m}$ and represents a $2 \%$ increase compared to 2001 ; and Value added per employee was $€ 29,500$.

As regards the future of the company, Trimo's long-term development is expected to enable a stable and constant growth. It is intended to satisfy Trimo's customers, employees and owners. Trimo will follow its vision and mission. They plan a minimum 5\% annual growth. They plan to constantly improve their business performance supported by the EFQM model of Business Excellence, Total Quality Management, Balanced Scorecard, Customer Relationship Management and other contemporary management tools.

Long-term growth of the company has been ensured by improved work in R\&D. Work of strong research teams organized in projects has been supplemented by the contributions of experts from other parts of the company. Trimo cooperates with universities and institutes from Slovenia and abroad. In 2002 over 30 associates from Slovenia, UK, Germany, Switzerland, Finland, Bulgaria and numerous other countries were involved and participated in the Trimo research projects. Monitoring of the balanced development structure ensures the balance between short- and long-term interests of the company including:

- Development of new products and systems is of essential importance for the future. In the last years this share has increased to over 50\%, mainly due to the reduction in improvements of the existing products.

- Improvements of the existing products and work procedures have prolonged the life-cycle of some products and decreased costs.

- $\quad$ Strategic and basic research started in 2001. Its share in the structure of research projects amounted to $12 \%$ in 2002 and has constantly increased.

The criteria for selecting research projects are economic justification and value added per project. They monitor the progress of new developments also when the product enters the market.

\section{Conclusion}

Companies everywhere are seeking to improve their performance, and really excellent ones can demonstrate outstanding results for all their stakeholders, including customers, shareholders, a government, employees and the community. The development and implementation of quality management systems have made considerable progress since the introduction of the ISO 9000 standard series in 1987. Companies operating under hard competitive conditions have to become better to improve their competitive position. This means meeting customers' needs and expectations better than competitors reducing cycle time in order to become quicker and more 
flexible, and cutting costs in order to offer better prices. The improvement can go on in small steps as continuous improvement. It can also soar jumps by re-engineering. What a quality management system emphasizes is the organisational ability to satisfy customer needs precisely and profitably involving all members of an organisation.

In the paper we discussed the business excellence from the European Foundation for Quality Management (EFQM) Excellence model point of view. We showed how employee results, customer results, and favourable society results are achieved through leadership driving policy and strategy, people, partnerships and resources, and processes, which ultimately lead to excellence in key performance results in a manufacturing company that won the 2002 Slovene National Quality Award based on the EFQM Excellence model. In Trimo, business excellence approach provides them with a unifying focus and integrates efforts of all employees, from top management to line staff, to continuously improve their every business operation for customer satisfaction. Quality management in Trimo helps to assure customer focus, give employees clear roles for quality management, and facilitates continuous improvement. All these are reflected in their resulting organizational performance: increased customer and employee satisfaction, and improved market performance and productivity. The model of Business Excellence has been used in the process of self-evaluation since 1997 and the company has participated in the process of Business Excellence of the Republic of Slovenia since 1998. We presented the case of a very successful manufacturing company. We believe that our findings and main conclusions regarding the case of Trimo can be applied to all companies facing transition period difficulties, operate in turbulent environments and want to set out for a journey of achieving business excellence.

\section{References}

1. Annual Report 2002, Trimo.

2. Atkinson, A. A., Waterhouse, J. H., and Wells, R. B., (1997), 'A Stakeholder Approach to Strategic Performance Measurement ', Sloan Management Review, spring: 25-37.

3. Business Excellence Report 2002, Trimo.

4. Customer Satisfaction Report 2003, Trimo.

5. Fink, R. L., (2000), 'Quality' in Barry J. Brinker (ed.), Guide to Cost Management, (New York: John Wiley \& Sons).

6. Kaplan, R. S., Atkinson, A. A., (1998), Advanced Management Accounting, (Upper Saddle River: Prentice Hall).

7. Kaplan, R. S., Norton, D. P., (1992), 'Balanced Scorecard - Measures That Drive Performance', Harvard Business Review, 70(1): 71-79.

8. Kaplan, R. S., Norton, D. P., (1996), The Balanced Scorecard - Translating Strategy into Action, (Boston: Harvard Business School Press).

9. Kaplan, R. S., Norton, D. P., (1999), 'Why Does Business Need a Balanced Scorecard?' in James B. Edwards (ed.), Emerging Practices in Cost Management, (Boston: WG\&L/RIA Group).

10. Kaplan, R. S., Norton, D. P., (1999a), 'Why Does Business Need a Balanced Scorecard? (Part 2)' in James B. Edwards (ed.), Emerging Practices in Cost Management, (Boston: WG\&L/RIA Group).

11. Kennedy, M. E., (2004), 'Using Customer Relationship Management to increase profits', Strategic Finance, March: 37-42.

12. Khan, Z. U., (2000), 'Cost of Quality' in Barry J. Brinker (ed.), Guide to Cost Management, (New York: John Wiley \& Sons).

13. Mackerron, G. C., Masson, R., McGlynn, M., (2003), 'Self assessment: use at operational level to promote continuous improvement', Production Planning \& Control, 14(1): 82-89.

14. Maguire, W., Putterill, M., (2000), 'Continuous Improvement in Turbulent Times' in Barry J. Brinker (ed.), Guide to Cost Management, (New York: John Wiley \& Sons).

15. Oakland, J., Tanner, S., and Gadd, K., (2002), 'Best Practice in Business Excellence', Total Quality Management, 13(8): 1125-1139.

16. Porter, L. J., Tanner, S. J., (2004), Assessing Business Excellence, (Oxford: Elsevier ButerworthHeinemann).

17. Rampersad, H. K., (2001), Total Quality Management: An Executive Guide to Continuous Improvement, (Berlin: Springer). 
18. Russell, R. S., Taylor, B. W. III, (1998), Operations Management: Focusing on Quality and Competitiveness, (Upper Saddle River: Prentice Hall).

19. Sandbrook, M., (2001), 'Using the EFQM Excellence Model as a framework for improvement and change', Journal of Change Management, 2(1): 83-90.

20. Seghezzi, H. D., (2001), 'Business Excellence: What is to be done?' Total Quality Management, 12(7\&8): 861-866.

21. Skubic, I., Leon, L., and Kern, K., (2004), The National Quality Award in Slovenia: The Slovenian Business Excellence prize. (http://www.mirs.si/PRSPO/objave/Bratislava-predstavitev_2_zv.pdf)

22. Stamatis, D. H., (1997), TQM Engineering Handbook, (New York: Marcel Dekker).

23. Tekavcic, M., Peljhan, D., (2003), 'Insights into managerial tools related to cost management in Slovenian companies', Zbornik radova Ekonomski fakultet Rijeka, 21(1): 83-99.

\section{Endnotes}

1. For more detail on this and other national and international quality awards consult Mackerron et al, 2003; Oakland et al., 2002; Porter and Tanner, 2004; Sandbrook, 2001; Seghezzi, H. D., 2001.

2. From now on, we will use the abbreviated form of the name of the company that is Trimo. The case of Trimo is based on the four main sources of data: Trimo's Annual Report 2002, Trimo's Business Excellence Report 2002, Customer Satisfaction Report 2003, and interviews with the top management.

3. For discussion on Customer Relationship Management (CRM) consult, for example, Kennedy, 2004.

4. Balanced Scorecard is thoroughly discussed in Kaplan and Norton, 1992, 1996, 1999, 1999a; Maguire and Putterill, 2000.

5. $\quad$ For more detail on stakeholder approach see Atkinson et al., 1997.

6. For more on contemporary management tools see, for example, Tekavcic, Peljhan, 2003.

Notes 
Notes 